\section{Duration of in vivo Effects of L-Asparaginase on Experimental Metastasis}

L-ASPARAGINASE has been used to treat various neoplasms in man and animals ${ }^{1-4}$, and was at first believed to act only on malignant cells which are dependent on asparagine. Clinical investigations, however, indicated that $\mathrm{L}$-asparaginase could itself be antigenic ${ }^{5}$ and have serious side effects. Moreover, L-asparaginase has been found to lead to suppression of phytohaemagglutinin-induced blastogenesis of human lymphocytes $^{6-8}$. Depression of the immune response to sheep red blood cells in mice treated with the enzyme has been reported ${ }^{9}$. Inhibition of the graft versus host reaction in rats and mice ${ }^{10}$ as well as reduction of the immune reactivity to an allografted tumour ${ }^{11}$ have also been observed.

The amounts of L-asparaginase necessary to produce regression of sensitive tumours have been worked out, but the frequency of administration required for optimal in vivo effects is not known. We report here the effects of L-asparaginase on the incidence of experimental metastasis and describe an assay to determine the duration of in vivo effects of a single dose of the enzyme.

B16 melanoma adapted to grow in tissue culture was used in C57BL/6J mice. In vitro cytotoxicity studies with various concentrations of L-asparaginase (1-50 IU $/ \mathrm{ml}$. media) revealed no inhibition of growth. Five groups of mice (12-14 weeks old) were injected intraperitoneally with $5,000 \mathrm{IU} / \mathrm{kg}$ of $\mathrm{L}$ asparaginase (Merck, Sharp, and Dohme) each day; control groups were injected with saline. The start of treatment ranged from 3 days before to 3 days after intravenous inoculation of 50,000 B16 melanoma cells. Treatments were carried out daily until the seventh day after injection of tumour cells. Mice were killed on the fourteenth day and their lungs were removed. Pulmonary metastases were counted under a dissecting microscope. Student's $t$ test was used in all evaluations of differences between means of each treatment group and its matched control. The results (Table 1) demonstrated that there were significantly more lung metastases $(P<0.001)$ in the mice treated with L-asparaginase before or on the day of tumour inoculation, compared with controls. No differences in the incidence of metastases were demonstrable between mice treated with L-asparaginase after tumour cell injection and controls.

Table 1 Incidence of Lung Metastases in Mice injected Intravenously with Melanoma Cells and treated with L-Asparaginase or Saline

No. of lung metastases *

Start of treatment

3 days before tumour $\dagger$

2 days before tumour $\dagger$

1 day before tumour $\dagger$

Same day as tumourt

1 day after tumour $\ddagger$

2 days after tumour $\ddagger$

3 days after tumour
Table 2 Duration of in vivo Effects of a Single Dose of L-Asparaginase on the Incidence of Experimental Metastasis

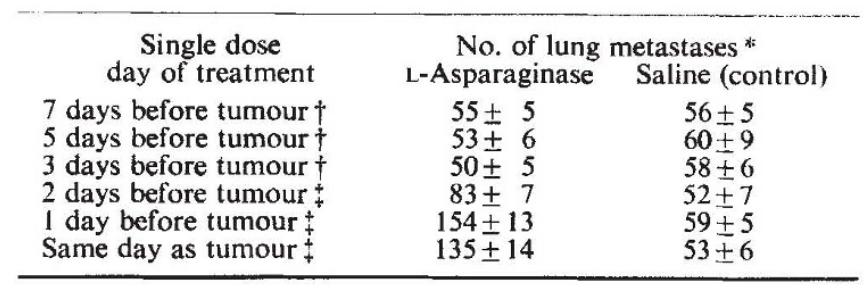

* Mean number of lung nodules in seven animals (per group).

$\uparrow$ Comparison of L-asparaginase and saline treated animals demonstrated no difference in the number of lung metastases.

\$ The number of lung metastases in $L$-asparaginase and saline treated controls differed significantly $(P<0.001)$.

either on the same day, or 1 or 2 days before tumour cell injection, than in the controls. On the other hand, in animals treated with L-asparaginase 3 or more days before tumour cell injection there was no increase in the number of lung metastases.

Thus we can conclude that L-asparaginase increases the incidence of pulmonary metastases, and that this increase may be due to host immunosuppression. Furthermore, in our system the duration of this effect after a single dose has been found to be about $48 \mathrm{~h}$, so that administration of L-asparaginase to achieve immunosuppression might only be necessary every 2 or more days.

This work was supported in part by grants from the US Public Health Service and the American Cancer Society.

Department of Pathology, ISAIAH J. FIDLER

School of Dental Medicine,

University of Pennsylvania,

Philadelphia,

Pennsylvania 19104

Received August 11; revised December 6, 1970.

1 Boyse, E. A., Old, L. J., Campbell, H. A., and Mashburn, L. T., J. Exp. Med., 125, 17 (1967).

2 Haskell, C. M., Canellos, G. P., Leventhal, G. G., Carbone, P. P., Block, J. R., Serpick, A. A., and Selawry, O. S., New Engl. J. Med., 281, 1028 (1969).

3 Oettgen, H. F., and Schiten, H. K., Klin. Woch., 47, 65 (1969).

4 Old, L. J., Boyse, E. A., Campbell, H. A., Brodey, R. S., Fidler, I. J., and Teller, J. D., Cancer, 20, 1066 (1969).

${ }^{5}$ Khan, A., and Hill, J. M., J. Lab. Clin. Med., 73, 846 (1969).

6 Astaldi, G., Burgio, G. R., Biscatti, G., Astaldi, A., and Ferfoglia, L., Lancet, i, 748 (1969).

7 Astaldi, G., Bargio, G. R., Kro, J., Genova, R., and Astaldi, A. A., Lancet, i, 423 (1969).

8 Weiner, M. S., Waithe, W. I., and Hirshhorn, K., Lancet, i, 748 (1969).

9 Schwartz, R. S., Nature, 224, 275 (1969).

10 Hobik, H. P., Naturwissenschaften, 4, 217 (1969).

${ }^{11}$ Schulten, K.' S., Giraldo, G., Boyse, E. A., and Oettgen, H. F., Lancet, i, 645 (1969).

\section{Rapid Cell Culture Assay Technique for Murine Leukaemia Viruses}

Mean number of lung nodules in eight animals (per group). differed significantly $(P<0.001)$.

$\ddagger$ No statistical differences in the number of lung metastases were demonstrated.

We then determined the duration of the effect of a single dose of L-asparaginase on the incidence of experimental metastasis. C57 mice, divided into six treatment and control groups, received a single intraperitoneal injection of $5,000 \mathrm{IU} / \mathrm{kg}$ of $\mathrm{L}$-asparaginase or of saline. Injections were given at different times, from 7 days before, to the same day as the intravenous injection of 60,000 B16 melanoma cells. Animals were killed 14 days later, and the lung metastases were counted. The results (Table 2) showed that there were significantly more lung metastases $(P<0.001)$ in mice treated once with $\mathrm{L}$-asparaginase
INFECTION of susceptible mouse cells in culture with murine leukaemia viruses (MLV) does not cause any observable change in cellular morphology, even though continuous virus replication in these cells can often be demonstrated. Complement-fixation ${ }^{1}$ and fluorescent antibody ${ }^{2}$ techniques as well as interference ${ }^{3}$ or potentiation ${ }^{4}$ of focus formation by "defective" murine sarcoma viruses have all been used successfully to detect and to quantitate in vitro infection of mouse cell cultures with MLV. These techniques, however, are less than ideal because they involve special reagents and lengthy incubation, or because they are relatively insensitive. Klement et $a .^{5}$ have shown that the $\mathrm{XC}$ cell line ${ }^{6}$, derived from a rat 